\title{
Joining of Single-Crystal Sapphire to Alumina Using Silicate Glasses
}

\author{
Satoru FUJITSU, Shozaburo ONO, Hiroaki NOMURA, Masaaki KOMATSU, Katuhiro YAMAGIWA, \\ Eduarudo SAIZ* and Antony P. TOMSIA* \\ Department of Materials Science and Ceramic Technology, Shonan Institute of Technology, \\ 1-1-25, Tsujido-Nishikaigan, Fujisawa-shi, Kanagawa 251-8511 \\ *Materials Sciences Division, Lawrence Berkeley National Laboratory, Berkeley, CA 94720, USA
}

\section{ケイ酸塩ガラスを用いたサファイア単結晶とアルミナとの接合}

\author{
藤津 悟 · 小野将三郎 · 野村洋明 · 小松正明 · 山極克洋 · Eduarudo Saiz* · Antony P. Tomsia* \\ 湘南工科大学マテリアル工学科, 251-8511 藤沢市辻堂西海岸 1-1-25 \\ *ローレンスバークレー国立研究所, Berkeley, CA 94720, USA
}

\begin{abstract}
The joining of a sapphire single crystal plate to alumina ceramic tube is fabricated successfully using $34 \mathrm{CaO}$. $30 \mathrm{Al}_{2} \mathrm{O}_{3} \cdot 36 \mathrm{SiO}_{2}$ glass as an interlayer. This glass showed good adhesion performance to alumina ceramics and sapphire single crystal. The joint with no crack was obtained by heating at $1550^{\circ} \mathrm{C}$ for 10 min and slow cooling from $1200^{\circ} \mathrm{C}$ to room temperature. From the thermal shock test, the half of the specimens showed the cracks after quenching from $225^{\circ} \mathrm{C}$ to $0^{\circ} \mathrm{C}$, but all specimens showed no cracks after quenching from $200^{\circ} \mathrm{C}$ to $0^{\circ} \mathrm{C}$. The specimen, composed of alumina tube-sapphire plate-alumina tube showed the comparable bending strength to the specimen composed of alumina tube-alumina tube.
\end{abstract}

[Received December 25, 2002; Accepted April 21, 2003]

Key-words : Alumina, Sapphire, Joining, Adhesion, High temperature performance

\section{Introduction}

Many promising applications for ceramics require fabrication of complex or large assemblies by joining simpler components formed (in many cases) from different materials. Successful joining procedures result in bonds that are strong, reliable, and relatively inexpensive to manufacture. Ceramic joining can be divided into three types: (1) direct ceramic to ceramic joining by solid-state diffusion, (2) joining using metallic interlayers, and (3) joining using oxide interlayers (vitreous or crystalline). ${ }^{1)-3 \text { ) }}$

Alumina is an important ceramic material, and consequently, the joining of alumina has been the subject of a large number of experimental and theoretical studies in which the three approaches mentioned above have been applied. ${ }^{4-14)}$ In this respect, joining with oxide interlayers has several merits: (1) optimum high-temperature performance can be achieved in oxidizing environments, (2) joining does not involve highly polished surfaces, and (3) lower bonging loads are usually required. Several oxides such as alkali or alkaline earth borosilicate, ${ }^{11)} \mathrm{CaO}-$ $\mathrm{Al}_{2} \mathrm{O}_{3},{ }^{10)} \mathrm{MnO}-\mathrm{Al}_{2} \mathrm{O}_{3}-\mathrm{SiO}_{2},{ }^{12)} \mathrm{MgO}-\mathrm{Al}_{2} \mathrm{O}_{3}-\mathrm{SiO}_{2}, \mathrm{CaO}-$ $\mathrm{Al}_{2} \mathrm{O}_{3}-\mathrm{SiO}_{2},{ }^{10), 13), 14)}$ etc., have been employed as an interlayer to join alumina ceramics. In our previous research regarding alumina joining, we selected the $\mathrm{CaO}-\mathrm{Al}_{2} \mathrm{O}_{3}-\mathrm{SiO}_{2}$ glass system in regard to its high melting point and chemical stability at high temperature. ${ }^{14)}$ The composition was chosen from the results of sessile drop test on sapphire plate. The results of sessile drop tests for some $\mathrm{CaO}-\mathrm{Al}_{2} \mathrm{O}_{3}-\mathrm{SiO}_{2}$ glasses (indicated in Fig. ${ }^{15)}$ ) are shown in Table 1.16) Using the optimum material $\left(\mathrm{G}-3: 36 \mathrm{CaO} \cdot 30 \mathrm{Al}_{2} \mathrm{O}_{3}\right.$. $34 \mathrm{SiO}_{2}$ ) as an interlayer (having a low contact angle and forming no cracks in sapphire plate), a strong alumina joint was prepared (320 MPa by 4 -points bending test). ${ }^{14)}$

In the present work, we apply this material to join polycrystalline alumina tubes and single-crystal $\mathrm{Al}_{2} \mathrm{O}_{3}$ (sapphire) plates. The joining technique of sapphire to polycrystalline alumina is important for fabricating the transparent windows needed in high-temperature lamp designs or tubes for metal gas lasers kept at high temperatures

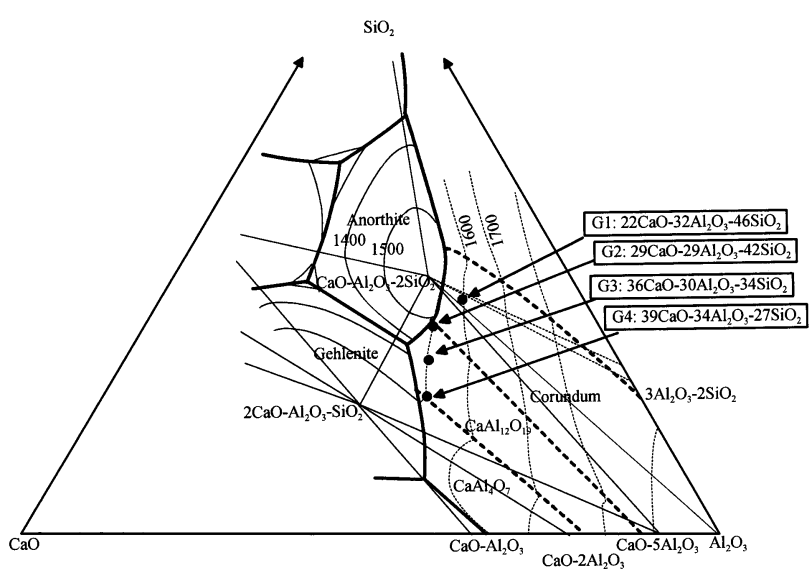

Fig. 1. Equilibrium phase diagram for $\left.\mathrm{CaO}-\mathrm{Al}_{2} \mathrm{O}_{3}-\mathrm{SiO}_{2} \cdot{ }^{15}\right)$

Table 1. Results of Sessile Drop Tests for Some $\mathrm{CaO}-\mathrm{Al}_{2} \mathrm{O}_{3}-\mathrm{SiO}_{2}$ Glasses on Sapphire

\begin{tabular}{|l|c|c|c|c|}
\hline & G-1 & G-2 & G-3 & G4 \\
\hline $\begin{array}{l}\text { composition }^{1)} \\
\mathrm{CaO}: \mathrm{Al}_{2} \mathrm{O}_{3}: \mathrm{SiO}_{2}\end{array}$ & $22: 32: 46$ & $29: 29: 42$ & $36: 30: 34$ & $39: 34: 27$ \\
\hline softening temperature & & & & \\
\hline contact angle & $1550^{\circ} \mathrm{C}$ & $1060^{\circ} \mathrm{C}$ & $1050^{\circ} \mathrm{C}$ & $1010^{\circ} \mathrm{C}$ \\
\hline crack in sapphire plate $^{3)}$ & $17^{\circ}$ & $19^{\circ}$ & $11^{\circ}$ & $14^{\circ}$ \\
\hline
\end{tabular}

1) weight ratio

2) observed by telescope through the pin hole

3) observed visually after the test

The assembly (a small glass cube $(1 \times 1 \times 1 \mathrm{~mm})$ on a sapphire plate $(1 \mathrm{~mm}$ in thickness) $)$ was placed in a tube-type furnace and heated in air up to $1600^{\circ} \mathrm{C}$ and then cooled with constant heating and cooling rates of $5^{\circ} \mathrm{C}$.

$\left(>1000^{\circ} \mathrm{C}\right) .{ }^{17)}$ In spite of its importance, there has been no report on the practical utility of such a joining. Some resear- 
chers have joined sapphire to polycrystalline alumina in order to create an experimental model for evaluating the migration of the grain boundary, where they employed the direct joining method by solid state diffusion. ${ }^{7)}{ }^{18)}$ Tomsia et al. suggested that the oxide interlayer was useful in light of the simplicity of the fabricating process, and they noted some candidates of such materials. ${ }^{19)}$

In the present report, we show the joining of a sapphire plate and a polycrystalline alumina tube using a $36 \mathrm{CaO}$. $30 \mathrm{Al}_{2} \mathrm{O}_{3} \cdot 34 \mathrm{SiO}_{2}$ interlayer. Joint strength is measured using the four-point bending test, and high-temperature performance is evaluated by means of a gas-leak test. The properties and microstructures of the joints are explained in terms of the reactions that occur during the bonding process.

\section{Experimental procedure}

\subsection{Glass}

The glass $\left(36 \mathrm{CaO} \cdot 30 \mathrm{Al}_{2} \mathrm{O}_{3} \cdot 34 \mathrm{SiO}_{2}\right.$, in mass $\left.\%\right)$ was prepared from high-purity $\mathrm{CaCO}_{3}, \mathrm{Al}_{2} \mathrm{O}_{3}$ and $\mathrm{SiO}_{2}$ powders (99.99\% , from Kojundo Chemical Laboratory Co., Ltd.) in 50 -gram batches. The glass components were mixed in isopropanol and dried in air at $50^{\circ} \mathrm{C}$ for $12 \mathrm{~h}$. The mixture was heated at $1000^{\circ} \mathrm{C}$ for $2 \mathrm{~h}$ to decompose the $\mathrm{CaCO}_{3}$ and subsequently melted at $1650^{\circ} \mathrm{C}$ for $4 \mathrm{~h}$ in a platinum crucible. Finally, the melt was cast on a stainless-steel plate preheated to $300^{\circ} \mathrm{C}$. At the end of this process, a transparent glass plate was obtained.

\subsection{Joining}

The glass was ground in an agate mortar. The resulting powder was mixed with 20 mass $\%$ of aqueous organic binder (from Lion Corp.), and the slurry was tape-cast using the doctor-blade method. The thickness of the green sheet was $400 \mu \mathrm{m}$. The sheet was cut into a ring with the same dimensions as the alumina tubes to be bonded. Two types of alumina tubes (SSA-S, from Nikkato Corp.) were used, with outside and inside diameters of $25 \times 18 \mathrm{~mm}$ and $10 \times 6$ $\mathrm{mm}$, respectively. The sapphire plates used for bonding (A-plane, from Sinkosha Co., Ltd.) had a thickness of $1 \mathrm{~mm}$ and a mirror surface finish. Prior to bonding, the sapphire plates were cut into squares, with the side length equal to the outside diameter of the alumina tube to be joined. Four types of samples were prepared (Fig. 2). The assemblies were heated at $1550^{\circ} \mathrm{C}$ for $10 \mathrm{~min}$ and cooled at $10^{\circ} \mathrm{C} / \mathrm{min}$ from $1550^{\circ} \mathrm{C}$ to $1200^{\circ} \mathrm{C}$. From $1200^{\circ} \mathrm{C}$ to room temperature, the cooling rates were slower $\left(<5^{\circ} \mathrm{C} / \mathrm{min}\right.$ for the $10 \times 6 \mathrm{~mm}$ tubes and $<2^{\circ} \mathrm{C} / \mathrm{min}$ for the $25 \times 18 \mathrm{~mm}$ tubes). Specimens of Types III and IV were supported during joining by alumina rods attached with $\mathrm{Pt}$ wire in order to prevent slippage. Bonds between the sapphire and the larger alumina tubes $(25 \times 18 \mathrm{~mm})$ were prepared only in the Type II configuration.

The microstructure and phases present in the glass layer were analyzed using scanning electron microscopy (SEM; JEOL T-6500) and X-ray diffraction (XRD) on fractured surfaces and polished cross sections.

\subsection{Gas leakage, thermal shock, and four-point bend-} ing tests

To test the integrity of the bonds at high temperature, we performed a gas-leak test using Type I specimens. Using the open end, the alumina tube was filled with nitrogen at $1.5 \times 10^{5} \mathrm{~Pa}$ and subsequently sealed. The assembly was heated to 1300 or $1500^{\circ} \mathrm{C}$ and then cooled (heating and cooling rates were $20^{\circ} \mathrm{C} / \mathrm{min}$ ). In parallel experiments, the inside of the alumina tube was evacuated to a pressure of $5 \mathrm{~Pa}$ and then heated under the same conditions. The pressures inside the tube were monitored using a Pirani vacuum gauge during heating and cooling in order to detect possible crack formation.

Resistance of the bonds to thermal shock was evaluated

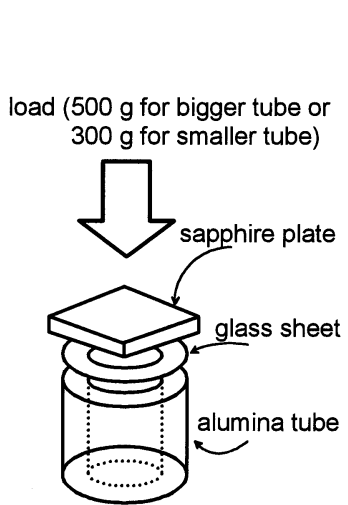
length of alumina tube) and type II $(25 \mathrm{~mm})$ (a) type I (200 $\mathrm{mm}$ in

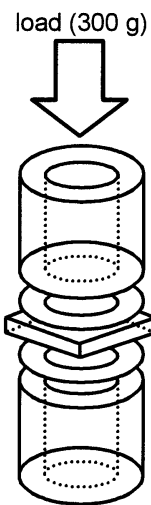

(b) type III

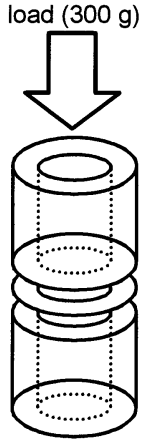

(c) type IV
Fig. 2. Assembling of the each specimen.
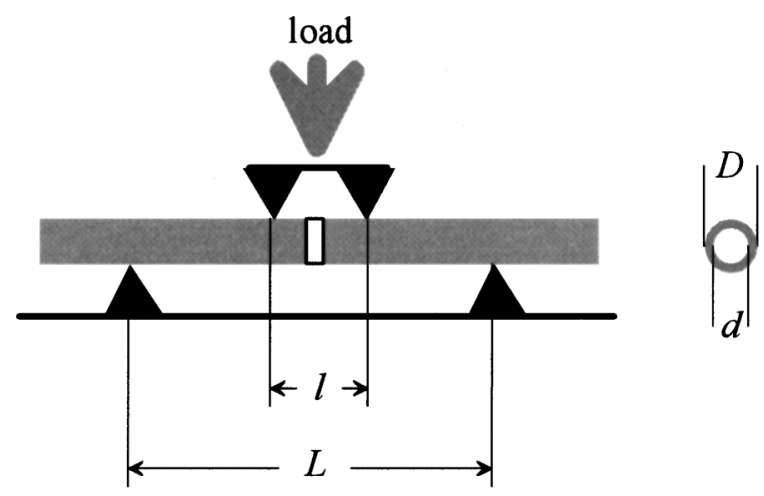

Fig. 3. Configuration of 4-points bending test.

qualitatively by observing the cracks formed in Type II specimens after heating at temperatures ranging between 100 and $300^{\circ} \mathrm{C}$ for $10 \mathrm{~min}$, and then dropping the samples into iced water.

As-prepared Types III and IV specimens were used to measure the room-temperature mechanical strength of the bond using the 4-points bending test (Shimadzu AGS$500 \mathrm{~A}$ ). The bending fixture has 10.0 and $40.0 \mathrm{~mm}$ spans, and the crosshead displacement rate was $0.5 \mathrm{~mm} / \mathrm{min}$. The configuration of this test is illustrated in Fig. 3.

\section{Results}

3.1 Gas-leak test

A sapphire plate joined to an alumina tube successfully with no visible cracks or voids. No gas leak or joint degradation was observed for the specimens heated to $1300^{\circ} \mathrm{C}$. However, the interlayer broke at $1425^{\circ} \mathrm{C}$ during the gaspressure test, and in vacuum tests the interlayer spread on the sapphire surface during the test up to $1500^{\circ} \mathrm{C}$ (Fig. 4 (a)). Since such a spreading was not observed in the vacuum test up to $1300^{\circ} \mathrm{C}$, it is judged that the spreading occurred above $1300^{\circ} \mathrm{C}$. Even though the softening temperature of the starting glass is $1050^{\circ} \mathrm{C}$, the gas-leak tests confirmed that the final softening temperature of the glass in the interlayer is higher than the starting condition.

\subsection{Thermal shock and bending tests}

During the thermal shock tests, the sapphire plates in the specimens fabricated with the larger alumina tubes $(25 \times 18$ $\mathrm{mm} \phi$ ) showed several cracks after dropping the tempera- 


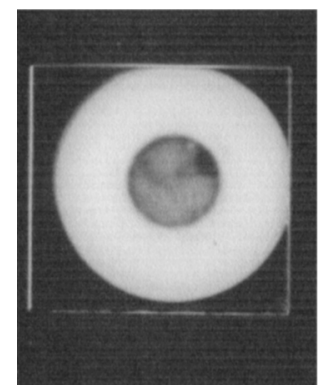

(a)

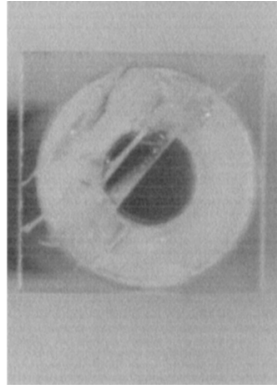

(b)
Fig. 4. (a) Specimen after the vacuum type of gas leakage test. The white area in the inside of sapphire plate is spread interlayer. (b) Specimen after dropping from $250^{\circ} \mathrm{C}$ into iced water. In both specimens, alumina tubes with $10 \mathrm{~mm} \phi$ are used.

Table 2. Comparison of Bending Strength and Thickness of Interlayer for Types III and IV Specimens

\begin{tabular}{|l|c|c|c|}
\hline & Type III & Type IV & As-Cut Tube \\
\hline No. of specimens & 6 & 6 & 4 \\
\hline Bending Strength $(\mathrm{MPa})$ & $\begin{array}{c}255,206,239, \\
267,209,248\end{array}$ & $\begin{array}{c}250,243,238, \\
218,242,330\end{array}$ & $\begin{array}{c}331,316,343, \\
306\end{array}$ \\
\hline $\begin{array}{l}\text { Mean Bending strength } \\
(\mathrm{MPa})\end{array}$ & 238 & 259 & 324 \\
\hline Thickness $(\mu \mathrm{m})$ & 16 & 14 & - \\
\hline
\end{tabular}

ture from $100^{\circ} \mathrm{C}$. However, those plates bonded to the smaller tubes $(10 \times 6 \mathrm{~mm} \phi)$ did not crack after dropping from temperatures as high as $200^{\circ} \mathrm{C}$. Small cracks were observed in half of the samples dropped from $225^{\circ} \mathrm{C}$, and large cracks formed in all specimens dropped from above $250^{\circ} \mathrm{C}$ (Fig. 4(b)).

Table 2 compares the bending strength and interlayer thickness of the different types of the samples. The bending strength $(\boldsymbol{\sigma})$ was normalized by using the following equation, ${ }^{20)}$

$$
\sigma=\frac{8 P D(L-l)}{\pi\left(D^{4}-d^{4}\right)}
$$

where $D(=10 \mathrm{~mm})$ and $d(=6 \mathrm{~mm})$ are the outside and the inside diameters of the tube, respectively, $L(=40 \mathrm{~mm})$ and $l(=10 \mathrm{~mm})$ the under and the upper span, respectively, and $P$ is the critical load at fracture. Equation (1) was derived from the section modulus of tube $(Z)$ as

$$
Z=\frac{\pi\left(D^{4}-d^{4}\right)}{32 D}
$$

and 4-points bending moment $(M)$ as

$$
M=\frac{P(L-l)}{4}
$$

Though the Type III specimen is not a tube strictly, we used Eq. (1) as a comparison. In a previous work, ${ }^{14)}$ the joined specimen used same alumina ceramics, glass and joining process with the same dimension according to the ASTM standard $(5 \times 3 \times 50 \mathrm{~mm})$ and its bending strength was 325 $\mathrm{MPa}$ on the average. This value is one of the highest performances of $\mathrm{Al}_{2} \mathrm{O}_{3}$ bonding with an oxide interlayer.

The ratio of the strengths of the Type IV specimens to that of the starting alumina tubes $(259 / 324 \mathrm{MPa})$ is very similar to previously reported values for the joining of alumina blocks using the same glass $(325 / 405 \mathrm{MPa})$. The smaller bending strength of the tube $(324 \mathrm{MPa})$ than that of
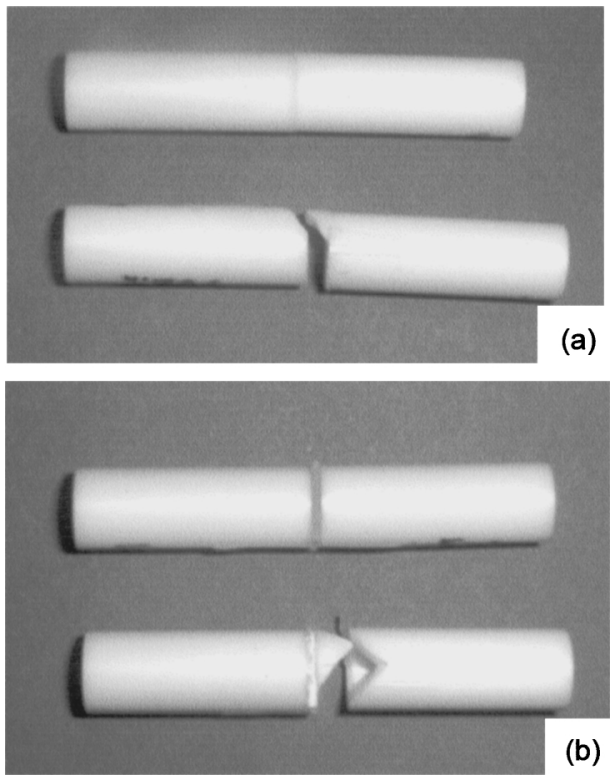

Fig. 5. Specimen of Type IV (a) and Type III (b).

the rectangular bar ( $405 \mathrm{MPa}$ ) should be due to the surface finishing. Typically, the fractures in the Type IV specimens started at the center of the interlayer and subsequently propagated into the alumina tube (see Fig. 5(a)). This result suggests a strong bond between the alumina and the oxide interlayer.

The strength of the Types III and IV specimens are comparable (though slightly smaller for Type III). The fracture started at the interlayer and progressed into the sapphire plate (Fig. 5(b)), indicating strong adhesion between the glass and the sapphire.

\section{Discussion}

Figure 5 shows a cross section of the bonded specimens. Even though some pores can be observed, a mostly homogeneous crack-free interlayer $(\sim 13 \mu \mathrm{m}$ thick $)$ formed between the alumina pieces. The interlayer is composed primarily of glass and needle-like crystals (Fig. 6(b)) that the XRD analysis of fracture surface identifies as corundum (Fig. 7). Sapphire dissolved into the interface layer during joining. Alumina dissolution is expected because the glass composition is in the primary field of $\mathrm{CaAl}_{12} \mathrm{O}_{19}$ (see Fig. $\left.1^{15)}\right)$. At the same time, the melt penetrated into the grain boundaries of the polycrystalline tube for distances up to $\sim 100 \mu \mathrm{m}$. It has been previously observed that this and similar molten compositions penetrate rapidly through the grain boundaries of alumina. ${ }^{14), 21), 22)}$ The starting glass composition is located within the compatibility triangle of anorthite $\left(\mathrm{CaO} \cdot \mathrm{Al}_{2} \mathrm{O}_{3} \cdot 2 \mathrm{SiO}_{2}\right)$, gehlenite $\left(2 \mathrm{CaO} \cdot \mathrm{Al}_{2} \mathrm{O}_{3}\right.$. $\mathrm{SiO}_{2}$ ), and $\mathrm{CaO} \cdot 6 \mathrm{Al}_{2} \mathrm{O}_{3}$. Alumina dissolution during bonding changes the composition of the interlayer, moving it towards the alumina side of the phase diagram. As a consequence, the softening point of the interlayer after bonding will be higher, and the joint can be used in high-temperature applications.

One of the key factors in fabricating a successful joint is matching the thermal expansion of the components. The reported thermal expansion coefficients of sapphire (normal and parallel to the $c$-axis) and polycrystalline alumina are $8.3 \times 10^{-6}, 9.0 \times 10^{-6}$ and $8.8 \times 10^{-6} /{ }^{\circ} \mathrm{C}$, respectively. ${ }^{23)} \mathrm{On}$ the other hand, the measured thermal expansion coefficient of the starting glass is $5.6 \times 10^{-6} /{ }^{\circ} \mathrm{C}$. A difference between 

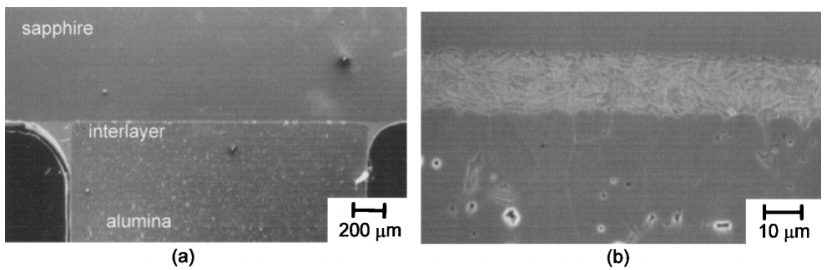

Fig. 6. Microstructure of joining of sapphire plate and alumina tube by oxide interlayer (a) and its magnification image of marked area $(b)$.

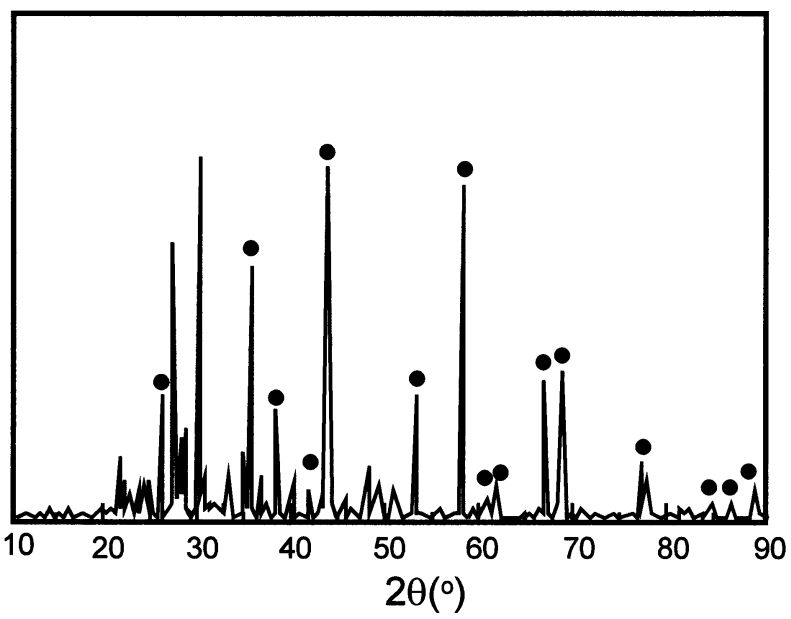

Fig. 7. X-ray diffraction profile for the fracture surface of alumina-alumina joining by $36 \mathrm{CaO} \cdot 20 \mathrm{Al}_{2} \mathrm{O}_{3} \cdot \mathrm{SiO}_{2}$ glass. Marked peaks were assigned to Corundum and the others have not assigned yet.

the thermal expansion coefficient of the glass and those of $\mathrm{Al}_{2} \mathrm{O}_{3}$ cannot be disregarded. Thus, we speculate that the dissolution and precipitation of alumina during bonding should increase the thermal expansion of the interlayer to values closer to those of $\mathrm{Al}_{2} \mathrm{O}_{3}$.

According to our results, the joining sequence can be described as follows. At $1050^{\circ} \mathrm{C}$, the glass interlayer softens. Previous research has shown that above $1300^{\circ} \mathrm{C}$, the glass exhibits a low contact angle on alumina that subsequently decreases to $11^{\circ}$ at $\left.1600^{\circ} \mathrm{C} .{ }^{14}\right)$ At temperatures higher than $1500^{\circ} \mathrm{C}$, the glass dissolves alumina from the sapphire and the polycrystalline material (Fig. 6) and simultaneously penetrates into the alumina grain boundaries like a wedge. In this way, a strong bond between the sapphire plate, the interlayer, and the alumina tube is achieved.

It is very important to control the joining times and temperatures. It has been shown that excess grain-boundary penetration and dissolution of alumina generate pores in the interlayer with a consequent decrease in strength. But on the other hand, very small grain-boundary penetration and dissolution of alumina leads to weak adhesion of the sapphire plate-interface-alumina tube.

\section{Summary}

The joining of a sapphire single crystal plate to a polycrystalline alumina tube was prepared using an oxide inter- layer $\left(36 \mathrm{CaO} \cdot 30 \mathrm{Al}_{2} \mathrm{O}_{3} \cdot 34 \mathrm{SiO}_{2}\right.$ in starting $)$, which showed good high temperature performance and high bonding strength. These characteristics were achieved by the dissolution of sapphire and alumina into the interface layer and the penetration of the melt of the interface layer into the grain boundary of polycrystalline alumina.

Acknowledgment This work was supported by a Grant-in-Aid for Scientific Research (B) from the Japanese Ministry of Education, Science, Sports, and Culture (14350357), and by the Director, Office of Energy Research, Office of Basic Energy Sciences, Division of Materials Sciences, of the U.S. Department of Energy under Contract No. DE-AC03-76SF00098.

\section{References}

1) Swartz, S. L., Majumdar, B. S., Skidmore, A. and Mutsuddy, B. C., Mater. Lett., Vol. 7, pp. 407-410 (1989).

2) Rice, R. W., "Advances in Joining Technology," Ed. by Burke, J. J., Gorum, A. E. and Torpinion, A., Brook Hill, Boston (1989) pp. 69-69.

3) Loehman, R. E. and Tomsia, A. P., Am. Ceram. Soc. Bull., Vol. 67, pp. 375-380 (1988).

4) Li, J. Q. and Xiao, O., J. Eur. Ceram. Soc., Vol. 22, pp. 1225-1233 (2002).

5) Hongoi, H., Zhihao, J. and Xiaotian, W., J. Mater. Sci., Vol. 29, pp. 5041-5046 (1994).

6) Torrecillas, R., Sainz, M. A. and Moya, J. S., Scripta Metallurgica et Materialia, Vol. 31, pp. 1031-1036 (1994).

7) Rödel, J. and Glaeser, A. M., J. Am. Ceram. Soc., Vol. 70, pp. C172-C175 (1987).

8) Rödel, J. and Glaeser, A. M., J. Am. Ceram. Soc., Vol. 73, pp. 3302-3312 (1990).

9) Finkelstein, Y., Wiederhorn, A. M., Hockey, B. J., Handwerker, C. A. and Blendell, J. E., "Ceramic Transactions, Vol. 7," Ed. by Handwerker, C. A., Blendell, J. E. and Kaysser, W. A., Am. Ceram. Soc. (1988) pp. $258-279$.

10) Knapp, J. T. and Cawley, J. D., “Metal-Ceramic Joining,” Ed. by Kumar, P. and Greenhut, V. A., The Minerals, Metals \& Materials Society (1991) pp. 181-181.

11) Barinov, S. M., Orlov, S. V. and Shevchenko, V. Va., J. Mater. Sci., Vol. 16, pp. 592-593 (1997).

12) Klomp, J. T. and Botden, Th. P. J., Am. Ceram. Soc. Bull., Vol. 49, pp. 204-211 (1970).

13) Klomp, J. T. and Botden, Th. P. J., Proc. Symp. Brit. Cer. Res. Assoc., Vol. 48, Spec. Publ. (1965) pp. 129-139.

14) Fujitsu, S., Yamagiwa, K., Saiz, E. and Tomsia, A. P., Proc. 6th International Symposium on Ceramic Materials and Components for Engine, Arita (1998) pp. 316-320.

15) "Phase Diagram for Ceramists," Am. Ceram. Soc. (1964) Fig. 630, pp. 219-219.

16) Nomura, A., Thesis of Shonan Institute of Technology (1999) [in Japanese].

17) Sugawara, Y., "Laser Kougaku," Ed. by Asami, Y., DenkidaiShuppankyoku, Tokyo (1988) pp. 66-66 [in Japanese].

18) Kitayama, M. and Glaeser, A. M., J. Am. Ceram. Soc., Vol. 85, pp. 611-622 (2002).

19) Tomsia, A. P., Glaeser, A. M. and Pask, J. A., "Joining Alumina to Sapphire for Copper Vapor Laser Tubes," Final Report for Naval Coastal System Center, Contract No. N61331-90-C-0005 (1990).

20) Mizuhara, A., Ida, T., Kurihara, K., Sasagawa, K., Shino, I. and Ueda, A., "Kouzokeisanbinran," Sangyotosho, Tokyo (1986) pp. 33-33 [in Japanese].

21) Flaitz, P. L. and Pask, J. A., J. Am. Ceram. Soc., Vol. 70, pp. 449-449 (1987).

22) Kim, J.-J. and Harmer, M. P., J. Am. Ceram. Soc., Vol. 81, pp. 205-205 (1998).

23) Kingery, W. D., Bowen, H. K. and Uhlmann, D. R., "Introduction to Ceramics," John Wiley \& Sons, New York (1976) pp. 594-594. 